\title{
PENGARUH MOTIVASI MENGHINDARI RIBA DAN PENGETAHUAN PRODUK KOPERASI SYARIAH TERHADAP KEPUTUSAN MENJADI NASABAH DI KOPERASI SIMPAN PINJAM PEMBIAYAAN SYARIAH (KSPPS) NUR HAYYU AMBARA NTB
}

\author{
Danang Prio Utomo ${ }^{1}$, Huzain Jailani ${ }^{2}$, Regita Ayu Cahyati ${ }^{3}$ \\ Universitas Hamzanwadi ${ }^{1,2,3}$ \\ danang_irenk@yahoo.com ${ }^{1}$,huzainjailani.farabi@gmail.com ${ }^{2}$ regitaayucahyati@gmail.com²
}

\begin{abstract}
This study aims to analyze partially and simultaneously the effect of the motivation to avoid usury and knowledge of sharia cooperative products on the decision to become a customer in the Sharia Savings and Loans Payment Cooperative Nur Hayyu Ambara NTB. This study uses quantitative methods. The sampling technique is Non Probability Sampling with Incidental Sampling sampling technique. The number of respondents in this study were 60 respondents. Data collection using a questionnaire and then processed using SPSS 16. Data analysis techniques using validity test, reliability test, classical assumption test, multiple linear regression test, partial test ( $\mathrm{t}$ test), simultaneous test (f test), and coefficient of determination test (R2). The results of this study indicate that partially the motivation to avoid usury has no significant effect on the decision to become a customer of the Sharia Savings and Loans Payment Cooperative Nur Hayyu Ambara, The results of the coefficient of determination (R2) show that the influence of motivation to avoid usury and product knowledge on the decision to become a customer of the Sharia Savings and Loans Payment Cooperative Nur Hayyu Ambara NTB is $31.1 \%$ while the remaining $69.9 \%$ is influenced by factors outside the model.
\end{abstract}

Keywords: Decision to become a customer; Motivation to avoid usury; Product knowledge

\section{PENDAHULUAN}

Koperasi merupakan suatu organisasi ekonomi rakyat yang berwatak social, atau suatu bentuk organisasi ekonomi rakyat yang eanggotaannya pada umumnya terdiri dari golongan yang berpendapatan rendah, yang mereka dirikan dengan tujuannya agar dengan bekerja sama dapat meningkatkan kesejahteraan mereka. Menurut Undang-undang pokok perkoperasian No.12 tahun 1967 bahwa koperasi Indonesia mempunyai tiga landasan diantaranya, landasan idil yaitu pancasila, landasan structural yaitu UUD 1945 dengan landasan geraknya pasal 33 ayat 1 UUD 1945 beserta penjelasannya serta landasan mental, yaitu setia kawan (gotong royong) dan kesadaran pribadi. Kelahiran koperasi syariah di Indonesia dilandasi oleh keputusam menteri (Kepmen) Koperasi dan UKM Republik Indonesia Nomor 91/Kep/M.KUKM/IX/2004 tangggal 10 September 2004 tentang petunjuk pelaksanaan Kegiatan Usaha Koperasi Jasa Keuangan Syariah. Keputusan menteri ini memfasilitasi berdirinya koperasi syariah menjadi 
Koperasi Jasa Keuangan Syariah (KJKS) atau Unit Jasa Keuangan Syariah (UJKS), dengan adanya system ini membantu koperasi serba usaha di Indonesia memiliki unit jasa keuangan syariah.

Berbagai jenis koperasi lahir seirama dengan aneka jenis usaha untuk memperbaiki kehidupan.Secara garis besar jenis koperasi yang ada dapat kita bagi menjadi 5 yaitu koperasi konsumsi, koperasi kredit (koperasi simpan- pinjam), koperasi produksi, koperasi jasa, dan koperasi serba usaha. Kepuasan nasabah sangat bernilai bagi perusahaaan sehingga tidak heran selalu ada slogan bahwa pelanggan adalah raja yang perlu dilayani dengan sebaik-baiknya, kepuasan pelanggan merupakan penilaian dari pelanggan atas pengguanan barang ataupun jasa dibandingkan dengan harapan sebelum penggunaannya.

Koperasi syariah memiliki prinsip yang berbeda dengan koperasi konvensional. Perbedaan yang mendasar terletak pada keuntungan yang diperoleh, dimana pada koperasi konvensional dikenal dengan perangkat bunga sedangkan koperasi syariah menerapkan prinsip bagi hasil. Prinsip utama koperasi syariah terdiri dari larangan atas riba pada semua jenis transaksi. Dengan pelaksanaan aktivitas bisnis atas dasar kesetaraan (equity), keadilan (fairness), dan keterbukaan (transparency), pembentukan kemitraan yang saling menguntungkan serta keharusan memperoleh keuntungan usaha secara halal. Koperasi syariah juga dituntut harus mengeluarkan dan mengadministrasi zakat guna membantu mengembangkan lingkungan masyarakatnya. Dalam ajaran agama Islam melarang adanya bunga (riba), namun dalam praktiknya bentuk kegiatan usaha, produk dan jasa koperasi syariah yang secara konseptual tidak berdasar pada bunga kurang dimengerti oleh masyarakat. Tidak hanya itu, sebagian masyarakat sudah memahami apa itu koperasi syariah namun masih awam mengenai produk yang dimilikinya, sehingga menyebabkan masyarakat enggan menggunakan produk-produk yang ditawarkan namun hanya diminati bagi masyarakat yang ingin menabung untuk menghindari adanya unsur riba. Padahal fasilitas yang ditawarkan oleh koperasi syariah tidak kalah unggul dengan koperasi konvensional.

Beberapa faktor yang melatarbelakangi nasabah memilih koperasi syariah berasal dari luar maupun nasabah itu sendiri. Faktor-faktor yang mempengaruhi prefensi nasabah dalam menggunakan layanan koperasi syariah yang dipilih, yaitu : pertama, motivasi menghindari riba merupakan faktor yang ada dalam diri seseorang yang menggerakkan, mengarahkan perilaku untuk memenuhi tujuan tertentu. Dari hasil penelitian sebelumnya diketahui bahwa faktor utama nasabah mempertahankan hubungannya dengan bank syariah adalah ketaatan mereka terhadap prinsip syariah. Nasabah memutuskan untuk tetap mempertahankan koperasi syariah berkaitan dengan masalah keyakinan dan keimanan terhadap pengaharaman riba bagi umat islam. Kedua, pengetahuan yang dipahami nasabah menjadi faktor yang mempengaruhi prefensi nasabah dalam memilih layanan koperasi syariah. Menurut Kamus Besar Bahasa Indonesia (Indonesia, 2011), 
Utomo, dkk.

pengetahuan adalah sesuatu yang diketahui atau segala sesuatu tentang sesuatu hal, pengetahuan nasabah dalam hal ini terkait semua informasi yang dimiliki nasabah mengenai berbagai macam produk dan jasa serta pengetahuan lainnya yang terkait dengan produk dan jasa dan informasi yang berhubungan dengan fungsinya sebagai nasabah, khususnya pengetahuan akan koperasi syariah. Secara umum, pengetahuan konsumen mengenai koperasi syariah mencakup pengetahuan produk, pelayanan, serta pengeathuan tentang penerapan nilai-nilai syariah oleh koperasi syariah. Pemahaman dan pengertian mengenai koperasi syariah akan mempengaruhi keputusan yang akan dipilih oleh masyarakat. Jika pengetahuan tentang koperasi syariah rendah maka dalam memandang dan keinginan untuk menjadi nasabah koperasi syariah pastinya rendah pula.

Upaya yang harus dilakukan koperasi syariah dalam meningkatkan jumlah nasabah selain motivasi adalah dengan mempelajari dan mengamati hal-hal yang mempengaruhi pengambilan keputusan nasabah untuk menggunakan jasa suatu koperasi.Karena nasabah merupakan pusat perhatian perusahaan, maka faktor yang dapat memberikan pengaruh pada keputusan nasabah dalam memilih koperasi syariah adalah pengetahuan produk. Pengetahuan produk atau produk knowledge dapat diartikan sebagai pengetahuan yang dimiliki oleh konsumen mengenai produk atau jasa yang dikonsumsi.Pengetahuan produk diperlukan sebagai dasar suksesnya suatu produk, biasanya melalui penggunaan atau keterlibatan pada suatu produk. Pengetahuan konsumen tentang suatu produk yang diharapkan dapat mempengaruhi kepuasan secara positif, sebab suatu pengetahuan akan membuat tentang produk akan lebih realistis.

(Peter \& Donnelly, 2010) menyatakan bahwa product knowledge adalah seluruh informasi yang terkandung dalam suatu produk atau jasa yang diinterprestasikan oleh konsumen.Pemahaman konsumen terhadap suatau produk atau jasa dipengaruhi oleh tiga aspek dasar yaitu pengetahuan tentang karakteristik atau atribut produk, pengetahuan tentang manfaat produk, dan pengetahuan tentang kepuasan yang diberikan produk bagi konsumen. Pengetahuan nasabah berfokus pada informasi yang diketahui mengenai suatu hal tertentu.Pengetahuan tersebut mencakup pengetahuan produk, pengetahuan pembelian, dan pengetahuan pemakaian. Nasabah yang mengetahui mengenai produk dan jasa yang ditawarkan maka nasabah cenderung berminat untuk menggunakan jasa atau produk tersebut. Pada umumnya, nasazbah yang ingin melakukan pembelian sebuah produk selalu mencari pengenalan produk yang tujuannya untuk melakukan perbandinagn dan menambah pengetahuan yang dimiliki oleh nasabah terhadap suatu produk serta melakukan tinjauan langsung sesuai dengan kebutuhannya dan akan mempengaruhi kecendrungan dalam pengambilan sebuah keputusan.

Perilaku konsumen menurut (Kotler \& Armstrong, 2001) merupakan suatu proses 
penilaian dan pemilihan dari berbagai alternative sesuai dengan kepentingan-kepentingan tertentu dengan menetapkan suatu pilihan yang dianggap paling menguntungkan.

Berdasarkan beberapa pengertian diatas dapat disimpulkan bahwa perilaku konsumen berkaitan erat dengan proses pengambilan keputusan untuk menggunakan barang dan jasa untuk memuaskan kebutuhannya. Menurut, (Kotler \& Armstrong, 2001) faktor-faktor yang mempengaruhi tingkah laku konsumen adalah budaya, social, pribadi dan psikolog.

Pengertian riba menurut pendapat Syeikh Muhammad Abduh adalah penambahanpenambahan yang disyaratkan oleh orang yang memiliki harta kepada orang yang meminjam hartanya (uangnya), karena pengunduran janji pembayaran oleh peminjam dari waktu yang telah ditentukan (Romdhoni, Tho’in, \& Wahyudi, 2012). Menurut Prof DR Rachmat Syafie I M.A. riba diharamkan karena dua hal yakni, pertama adalnya kedzaliman; kedua adanya eksploitasi dalam kebutuhan pokok atau adanya gharar, ketidakpastian dan spekulasi yang tinggi. (Syafi'i, 2001). Menurut J Paul Peter dan Jerry C. Olson membagi pengetahuan menjadi tiga jenis pengetahuan produk yaitu pengetahuan tentang karakteristik atau atribut produk, pengetahuan tentang manfaat produk, dan pengetahuan tentang kepuasan yang diberikan produk bagi konsumen.

Adapun beberapa penelitian terkait dengan penelitian ini adalah 1). (Halimatus, 2018), Jurnal berjudul "Pengaruh Kualitas Produk dan Kualitas Pelayanan terhadap Kepuasan Nasabah Koperasi “SUMBER MAKMUR” Berbasis Syariah di Desa Sumber Bening Kecamatan Bringin Kabupaten Ngawi". Dimana hasil dari penelitia ini yakni terdapat pengaruh baik parsial dan simultan antara kualitas produk, kualitas pelayanan terhadap kepuasan nasabah, 2). Selanjutnya penelitia yang dilakukan oleh saudari (Isnawati, n.d.), Jurnal berjudul "Pengaruh Dimensi Kualitas Layanan Terhadap Kepuasan Nasabah Pada KSPPS Baitul Mal Wa Tanwil (BMT) Turi Sembada Kabupaten Sleman". Hasil penelitian menujukkan: a)tingkat dimensi kualitas pelayanan KSPPS BMT Turi Sembada dalam kategori sedang, b) tingkat kepuasan nasabah dalam kategori sedang dan c) terdapat pengaruh positif dan signifikan compliance, assurance, realibility, emphaty, respinsivenesss terhadap kepuasan nasabah dan tidak ada pengaruh tangible terhadap kepuasan nasabah serta terdapat pengaruh positif dan signifikan compliance, assurance, realibility, tangiable, emphaty, respinsivenesss secara bersama-sama terhadap kepuasan nasabah. 3) dan selanjutnya penelitia yabg dilakukan oleh saudara (Bahanan, 2012), Jurnal berjudul “ Analisis Rasio Keuangan Sebagai Alat Perbandinga Kinerja Keuangan Antara Koperasi Konvensional dan Koperasi Syariah”. Penelitian ini bertujuan untuk menganalisis kinerja keuangan antara koperasi konvensional dan kopeasi syariah serta menganalisis perbandingan kinerja keuangan dari masing-masing koperasi tersebut. Hasil penelitian ini menujukkan bahwa kinerja keuangan koperasi syariah lebih baik dari pada koperasi konvensional. 
Utomo, dkk.

Dari beberapa penelitian relevan yang ada, peneliti menganggap sangat penting untuk melakukan kajian penelitian dengan judul Pengaruh Motivasi Menghindari Riba Dan Pengetahuan Produk Koperasi Syariah Terhadap Keputusan Menjadi Nasabah Di Koperasi Simpan Pinjam Pembiayaan Syariah (KSPPS) Nur Hayyu Ambara Ntb

\section{METODOLOGI}

Metode penelitian merupakan langkah atau prosedur yang akan dilakukan untuk mengumpulkan data dalam rangka memecahkan masalah atau menguji hipotesis. Metode yang digunakan dalam penelitian ini adalah deskriptif kuantitatif yaitu penelitian menggambarkan atau menguraikan suatu keadaan atau kejadian sejelas mungkin dengan cara menggunakan kuesioner sebagai alat untuk mengumpulkan informasi dan keterangan yang diolah dengan menggunakan statistik, yaitu analisis regresi linear berganda untuk mengetahui hubungan secara linear antara dua atau lebih variable independent dengan variable dependent. (Sugiyono, 2019) Metode kuantitatif adalah metode yang digunakan terhadap data yang berwujud angka-angka dan cara pembahasannya dengan uji statistik, teknik perhitungan secara kuantitatif matematik dapat dilakukan sehingga dapat menghasilkan suatu kesimpulan yang berlaku umum didalam suatu parameter. Populasi dari penelitian ini yaitu nasabah KSPSS Nur Hayyu Ambara NTB yang berjumlah 150 orang. Populasi merupakan keseluruhan objek yang menjadi sasaran penelitian. Populasi disebut juga universum yaitu generalisasi yang terdiri atas objek atau subjek yang memiliki kualitas atau karakteristik tertentu yang ditetapkan oleh peneliti untuk dipelajari dan kemudian ditarik kesimpulan. Sampel dan Teknik Pengambilan Sampel, Sampel adalah bagian dari populasi yang akan diteliti secara mendalam. Menurut Sugiyono sample merupakan sebagian dari populasi atau dalam istilah matematika dapat disebut sebagai himpunan bagian populasi. Sedangkan metode pengambilan sampelnya menggunakan metode Slovin (Umar, 2005)

Populasi dalam penelitian ini berjumlah 150 orang, batas toleransi kesalahan adalah 0,1, maka besarnya sampel pada penelitian ini adalah

$$
\begin{aligned}
& \mathrm{n}=\mathrm{N} / 1+\mathrm{Ne}^{2} \\
& \mathrm{n}=150 / 1+150 \times 0,1^{2} \\
& \mathrm{n}=60
\end{aligned}
$$

60 orang yang di jadikan sampel di ambil dari keseluruhan masyarakat yang menjadi nasabah di KSPSS Nur Hayyu Ambara. Teknik pengambilan sampel dalam penelitian ini menggunakan Insidental Sampling. Insidental Sampling yaitu teknik penentuan sampel berdasarkan kebetulan, yaitu siapa saja yang kebetulan/insidental bertemu dengan peneliti dapat digunakan sebagai sampel. Peneliti menggunakan insidental sampling dengan pertimbangan bahwa 
peneliti telah menentukan kriteria subjek yang akan diteliti. Alasan berikutnya adalah insidental sampling dianggap paling tepat karena mewakili populasi. Merujuk pendapat diatas maka karakteristik sampel dalam penelitian ini adalah masyarakat yang menjadi nasabah KSPSS Nur Hayyu Ambara NTB.

\section{HASIL DAN PEMBAHASAN}

Dalam penelitian ini, jumlah responden adalah 60 responden, yaitu nasabah di KSPSS Nur Hayyu Ambara NTB. Perhitungan jumlah responden berdasarkan ketentuan sampel eror $10 \%$ dari populasi yang ada.

Tabel 1.Karakteristik berdasarkan tingkat usia

\begin{tabular}{ccc}
\hline Usia & Frekuensi & Presentase (\%) \\
\hline$<17$ & 0 & $\mathbf{0} \%$ \\
$17-25$ & 13 & $21,5 \%$ \\
$25-34$ & 20 & $33 \%$ \\
$35-43$ & 22 & $36,5 \%$ \\
$44-52$ & 5 & $\mathbf{9 \%}$ \\
$\mathbf{5 3}$ Keatas & 0 & $\mathbf{0 \%}$ \\
\hline Total & 60 & $\mathbf{1 0 0 \%}$ \\
\hline
\end{tabular}

Dari tabel diatas dapat dikatakan bahwa dalam penelitian ini yang menjadi subyek atau responden terdiri dari usia $<17$ tahun sebanyak 0 orang, dari 17-25 tahun sebanyak 13 orang, dari 25-34 tahun sebanyak 20 orang, dari 35-43 tahun sebanyak 22 orang, dari 44-52 tahun sebanyak 5 orang dan dari 53 tahun keatas sebanyak 0 orang. Dari tabel 2, dapat dikatakan bahwa dalam penelitian ini yang menjadi subyek atau responden memiliki pekerjaan yang terdiri dari pelajar 0 orang, Nelayan 10 orang, Guru 5 orang, Wiraswasta 23 Orang, PNS 7 Orang, dan Ibu Rumah Tangga sebanyak 15 orang. Sehingga dapat ditarik kesimpulan kebanyakan responden memiliki pekerjaan sebagai Wiraswasta yaitu sebanyak 23 responden.

Tabel 2. Karakteristik berdasarkan pekerjaan

\begin{tabular}{ccc}
\hline Pekerjaan Utama & Frekuensi & Presentase (\%) \\
\hline Pelajar & 0 & $\mathbf{0}$ \\
Nelayan & 10 & $\mathbf{1 6 , 6 \%}$ \\
Guru & 5 & $\mathbf{8 , 4 \%}$ \\
Wiraswasta & 23 & $\mathbf{3 8 , 4 \%}$ \\
PNS & 7 & $\mathbf{1 1 , 6 \%}$ \\
Ibu Rumah Tangga & 15 & $\mathbf{2 5 \%}$ \\
\hline Total & $\mathbf{6 0}$ & $\mathbf{1 0 0 \%}$ \\
\hline
\end{tabular}


Utomo, dkk.

Uji normalitas bertujuan untuk mengetahui apakah data penelitian berdistribusi normal atau tidak normal. Data yang normal adalah data yang menyebar merata dan polanya tidak menceng kekiri maupun kekanan. Untuk menguji normalitas, dalam penelitian ini peneliti menggunakan cara uji statistik Non - Parametric Kolmogorov.Smi rno v (K-S).Apabila nilai signifikansi lebih dari 0,05 maka residual terdistribusi secara normal. Berdasarkan hasil uji normalitas Kolmogorov Smirnov dapat diketahui berdistribusi normal. Hal ini dapat dibuktikan dari nilai ( Asymp.Sig.2 - tailed) pada motivasi menghindari riba, pengetabuan produk perbankan syariah, dan keputusan menjadi nasabah lebih besar dari 0,05 yaitu 0,852>0,05 maka dapat disimpulkan bahwa data berdistribusi normal.

Uji multikolinieritas digunakan untuk menguji apakah pada model regresi ditemukan adanya korelasi antar variabel independen.Model regresi yang baik tidak terjadi korelasi diantara variabel independen (bebas).Untuk mengetahui adanya gejala multikolinieritas dengan menggunakan nilai Variance Infaction Faktor (VIF) dan tolerance melalui SPSS. Apabila nilai VIF kurang dari 10 dan Tolerance lebih dari 0,1 maka dinyatakaan tidak terjadi multikolinieritas. Berdasarkan hasil uji multikolinearitas menunjukkan bahwa variabel X1(motivasi menghindari riba) memperoleh nilai VIF 1,000 dan tolerance 1,000 dan untuk variabel X2(pengetahuan produk perbankan syariah) memperoleh nilai VIF 1,000 dan nilai tolerance 1,000. Hasil kedua variabel tersebut lebih kecil dari 10 dan nilai tolerance lebih besar dari 0,1. Sehingga dapat disimpulkan bahwa penelitian ini bebas dari adanya multikolinearitas.

Uji heteroskedastisitas digunakan untuk mengetahui ada atau tidaknya penyimpangan asumsi heteroskedastisitas, yaitu adanya ketidaksamaan varian dari residual untuk semua pengamatanpada model regresi. Model regresi yang baik adalah tidak adanya gejala heterokedastisitas. Dalam penelitian ini, untuk menguji heteroskedastisitas menggunakan cara uji Glejser dengan meregresikan nilai absolute residual terhadap variabel independen. Apabila nilai signifikansi hitung lebih besar dari alpha 5\%, maka dapat disimpulkan bahwa tidak terjadi heteroskedastisitas.Tetapi jika nilai signifikansi hitung lebih kecil dari alpha 5\% maka dapat dikatakan terjadi heterokedastisitas. Berdasarkan hasil uji heteroskedastisitas menunjukkan bahwa nilai signifikansi X1(motivasi menghindari riba) sebesar 0,348 dan X2(pengetahuan produk koperasi syariah) sebesar 0,108 yang memiliki nilai lebih dari 0,05 maka dapat disimpulkan bahwa tidak terdapat heteroskedastisitas.

Berdasarkan analisis data, diperoleh nilai koefisien korelasi (R) sebesar 0,557. Hal ini menunjukkan bahwa terjadi hubungan yang kuat antara motivasi menghindari riba dan pengetahuan produk perbankan syariah terhadap keputusan menjadi nasabah. Koefisien determinasi digunakan untuk mengukur seberapa besar presentase perubahan dari variabel 
dependen bisa dijelaskan oleh perubahan dariindependen. Semakin tinggi nilai koefisien determinasi akan semakin baik kemampuan variabel independen dalam menjelaskan pengaruhnya terhadap variabel dependen. Berdasarkan hasil uji koefisien determinasi dapat diketahui bahwa $\mathrm{R}$ Square (R2) sebesar 0,311 atau 31,1\% yang menunjukkan bahwa terdapat pengaruh variabel motivasi menghindari riba dan pengetahuan produk koperasi syariah. Sedangkan sisanya (100\% $31,1 \%=69,9 \%$ ) dapat dijelaskan oleh variabel lain yang tidak terdapat dalam penelitian ini.

Regresi linear berganda adalah alat analisis peramalan nilai pengaruh dua variabel bebas atau lebih terhadap satu variabel terikat untuk membuktikan ada atau tidaknya pengaruh fungsional atau pengaruh kausal antara dua variabel bebas atau lebih dengan satuvariabel terikat.

Tabel 3. Hasil Analisis Regresi Linear Berganda Coefficients ${ }^{a}$

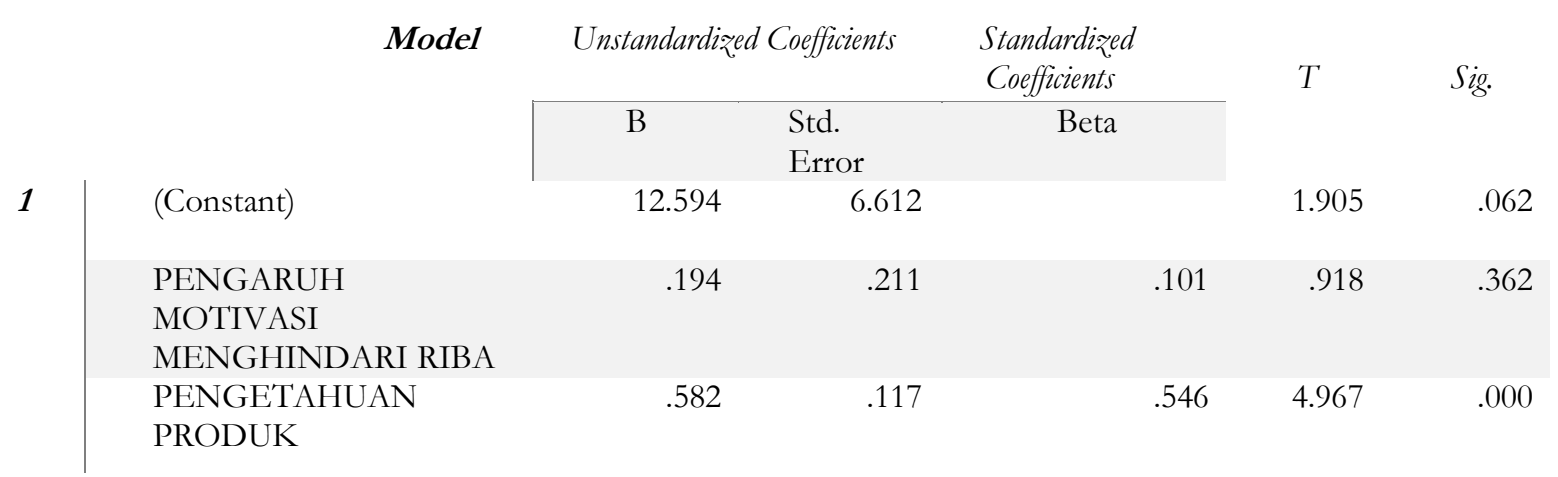

Berdasarkan hasil analisis, variabel motivasi menghindari riba, dapat diperoleh nilai thitung sebesar 0,918 sedangkan nilai $t_{\text {tabel }}$ 1,672, dapat disimpulkan bahwa nilai $t_{\text {hitung }} 0,918<1,672$ maka Ho diterima. Dengan nilai signifikansi lebih dari 0,05 yaitu $0,000(0,000<0,05)$. Nilai thitung negatif menunjukkan bahwa variabel $\mathrm{X}_{1}$ tidak mempunyai hubungan yang searah dengan $\mathrm{Y}$. Jadi, dapat disimpulkan bahwa variabel motivasi menghindari riba tidak berpengaruh positif signifikan terhadap keputusan menjadi nasabah. Berdasarkan tabel 4.17 variabel pengetahuan produk koperasi syariah, dapat diperoleh nilai $t_{\text {hitung }}$ sebesar 4,967 sedangkan nilai $t_{\text {tabel }}$ 1,672, dapat disimpulkan bahwa nilai $t_{\text {hitung }}>t_{\text {tabel }}(4,967>1,672)$ maka Ho ditolak. Dengan nilai signifikansi kurang dari 0,05 yaitu $0,000(0,000<0,05)$. Nilai thitung positif menunjukkan bahwa variabel $\mathrm{X}_{2}$ mempunyai hubungan yang searah dengan Y. Jadi, dapat disimpulkan bahwa variabel pengetahuan produk perbankan syariah berpengaruh signifikan terhadap keputusan menjadi nasabah.

Pada tabel di bawah, dapat diketahui bahwa nilai $F_{\text {hitung }}>F_{\text {tabel }}$ dengan nilai $12.837>3.160$ dan nilai probabilitas value atau taraf signifikan adalah $0,000<0,05$. Sehingga hasil uji hipotesisnya yaitu $\mathrm{H}_{1}$ diterima dan $\mathrm{H}_{0}$ ditolak.Hal ini dapat diartikan bahwa variabel motivasi menghindari riba 
Utomo, dkk.

$\left(\mathrm{X}_{1}\right)$ dan pengetahuan produk koperasi syariah $\left(\mathrm{X}_{2}\right)$ secara simultan berpengaruh secara signifikan terhadap keputusan menjadi nasabah.

Tabel 4. Hasil Uji F

ANOVA $^{\mathrm{b}}$

\begin{tabular}{lllcccc}
\hline \multicolumn{2}{c}{ Model } & $\begin{array}{c}\text { Sum of } \\
\text { Squares }\end{array}$ & Df & $\begin{array}{c}\text { Mean } \\
\text { Square }\end{array}$ & F & Sig \\
\hline $\mathbf{1}$ & Regression & 338.776 & 2 & & \\
\hline & Residual & 752.157 & 57 & & \\
\hline & Total & 1090.933 & 59 & & \\
\hline
\end{tabular}

\section{SIMPULAN}

Berdasarkan data yang diperoleh dari penelitian ini dan analisis yang telah dilakukan, maka kesimpulan yang dapat dikemukakan oleh penulis dalam penelitian ini adalah sebagai berikut: 1). Berdasarkan hasil pengujian menunjukkan bahwa secara parsial variable motivasi menghindari riba tidak berpengaruh signifikan terhadap keputusan menjadi nasabah. Hal ini didukung dengan hasil yang diperoleh dari uji signifikansi parsial (uji t) yang menghasilkan nilai $\mathrm{t}_{\text {hitung }}<\mathrm{t}_{\text {tabel }}(0,918<1,672)$ dan nilai signifikan 0,000 lebih kecil dari 0,05. Berdasarkan nilai kriteria, maka $\mathrm{H}_{0}$ diterima dan $\mathrm{H}_{\mathrm{a}}$ ditolak. 2). Berdasarkan hasil pengujian bahwa secara parsial variable pengetahuan produk berpengaruh signifikan terhadap keputusan menjadi nasabah. Hal ini didukung dengan hasil yang diperoleh dari uji signifikansi parsial (uji t) yang menghasilkan nilai $t_{\text {hitung }}>t_{\text {tabel }}(4,967>1,672)$ dan nilai signifikan 0,000 lebih kecil dari 0,05. Berdasarkan kriteria, maka $\mathrm{H}_{0}$ ditolak dan $\mathrm{H}_{\mathrm{a}}$ diterima. 3). Berdasarkan hasil pengujian menunjukkan bahwa secara Simultan variable motivasi menghindari riba dan pengetahuan produk berpengaruh signifikan terhadap keputusan menjadi nasabah, yang berarti jika variabel motivasi menghindari riba dan pengetahuan produk akan berpengaruh positif terhadap keputusan menjadi nasabah. Hal ini didukung dengan hasil yang diperoleh dari uji signifikansi simultan (uji f) yang menghasilkan nilai $\mathrm{f}_{\text {hitung }}<\mathrm{f}_{\text {tabel }}(12,837<3,160)$ dan nilai signifikan 0,000 lebih besar dari 0,05 sehingga besar pengaruhnya adalah 31,1\% sedangkan 69,9\% dipengaruhi oleh faktor lain yang tidak diteliti. Berdasarkan nilai kriteria, maka $\mathrm{H}_{0}$ ditolak dan $\mathrm{H}_{a}$ diterima.

\section{REFERENSI}

Bahanan, M. (2012). Analisis Rasio Keuangan Sebagai Alat Perbandingan Kinerja Keuangan Antara Koperasi Konvensional Dan Koperasi Syariah (Studi kasus pada Koperasi Wanita Kartika Candra Pandaan Pasuruan dan Koperasi BMT-UGT Sidogiri Pasuruan). 
Halimatus, S. (2018). Pengarub Kualitas Produk dan Kualitas Pelayanan Terhadap Kepuasan Nasabah Koperasi" Sumber Makmur” Berbasis Syariah Di Desa Sumberbening Kecamatan Bringin Kabupaten Ngawi. IAIN PONOROGO.

Indonesia, K. B. B. (2011). Jakarta. Republik Indonesia.

Isnawati, D. (n.d.). Pengarub Dimensi Kualitas Layanan Terhadap Kepuasan Nasabah Pada Koperasi Simpan Pinjam Pembiyaan Syariah (Kspps) Baitul Mal Wa Tanwil (Bmt) Turi Sembada.

Kotler, P., \& Armstrong, G. (2001). Prinsip-prinsip Pemasaran edisi ke VIII jilid 8. Jakarta: Penerbit Erlangga.

Peter, J. P., \& Donnelly, J. H. (2010). Marketing management. McGraw-Hill Higher Education.

Romdhoni, A. H., Tho'in, M., \& Wahyudi, A. (2012). Sistem Ekonomi Perbankan Berlandaskan Bunga (Analisis Perdebatan Bunga Bank Termasuk Riba Atau Tidak). Jurnal Akuntansi Dan Pajak, 13(1).

Sugiyono, P. (2019). Metode Penelitian Pendidikan (Kuantitatif, Kualitatif, Kombinasi, R\&D dan Penelitian Pendidikan)(A. Nuryanto. Alfabeta.

Syafi'i, A. M. (2001). Bank Syariah dari teori ke praktik. Jakarta: Gema Insani.

Umar, H. (2005). Metode penelitian untuk skripsi \& tesis bisnis. Edisi Baru, Cetakan Pertama. PT. Raja Grafindo Persada. Jakarta. 